ORIGINAL PAPER

\title{
RELATIONSHIP BETWEEN RADIOLOGICAL PARAMETERS AND PREOPERATIVE PULMONARY FUNCTION IN ADOLESCENTS WITH IDIOPATHIC SCOLIOSIS - PRELIMINARY STUDY
}

\section{ZALEŻNOŚĆ PARAMETRÓW RADIOLOGICZNYCH I PRZEDOPERACYJNYCH WARTOŚCI PARAMETRÓW ODDECHOWYCH U NASTOLETNICH CHORYCH ZE SKOLIOZĄ IDIOPATYCZNĄ - BADANIE WSTĘPNE}

\author{
Katarzyna Politarczyk ${ }^{1,2}$, Piotr Janusz ${ }^{1}$, Łukasz Stępniakk, Mateusz Kozinoga ${ }^{1,2}$, Tomasz \\ Kotwicki ${ }^{1}$ \\ 'Department of Spine Disorders and Pediatric Orthopaedics, University of Medical Sciences, \\ Poznan, Poland \\ ${ }^{2}$ Rehasport Clinic, Poznan, Poland
}

\section{ABSTRACT}

\section{Introduction}

Thoracic spine deformity in adolescents with idiopathic scoliosis (IS) has been suggested to impair pulmonary function. The number of the curve vertebrae, curve magnitude and decreased kyphosis angle in thoracic spine may contribute to decreased pulmonary parameters. The results of previous research on the relationship between the pulmonary function and radiographic parameters have not been consistent.

\section{Aim}

The aim of the study was to analyze the relationship of the thoracic curve magnitude, number of involved vertebrae and angle of thoracic kyphosis with the pulmonary parameters in adolescents with IS.

\section{Material and methods}

Preoperative pulmonary testing and radiographic examination were performed in 31 adolescents diagnosed with IS, aged $12-18$ years old (mean age $14.7 \pm 1.85$ ). Correlation and multiple regression analysis were performed to assess the relationship between radiological measurements and pulmonary parameters (Forced Vital Capacity (FVC) and Forced Expiratory Volume in One second (FEVl)).

\section{Results}

In $51 \%$ of the patients the pulmonary parameters were normal while $16 \%$ presented pulmonary impairment. Significant negative correlation between pulmonary parameters versus thoracic curve magnitude and pulmonary parameters versus number of the vertebrae involved was found. However, these parameters may explain $25.16 \%$ and $26.47 \%$ of the observed variability of the FVC and FEVl respectively. No significant correlation of pulmonary parameters versus thoracic kyphosis angle was found. 


\section{Conclusions}

Normal pulmonary parameters occurred in half of adolescents with idiopathic scoliosis qualified for surgical treatment. The magnitude of the thoracic curve and the number of involved vertebrae correlate negatively with the preoperative pulmonary parameters in adolescents with idiopathic scoliosis.

Keywords: pulmonary function testing, idiopathic scoliosis, radiological parameters

\section{STRESZCZENIE}

\section{Wstęp}

Skolioza idiopatyczna (SI) zlokalizowana w odcinku piersiowym kręgosłupa może mieć negatywny wpływ na parametry oddechowe. Liczba kręgów tworzących skrzywienie w odcinku piersiowym kręgosłupa oraz jego wielkość, a także utrata kifozy piersiowej mogą się przyczyniać do obniżenia wartości parametrów oddechowych. Wyniki wcześniej prowadzonych badań dotyczących wpływu parametrów radiologicznych na parametry oddechowe są niejednoznaczne.

\section{Cel}

Celem badania była analiza zależności pomiędzy wielkością kąta Cobba w odcinku piersiowym kręgosłupa, liczby kręgów tworzących łuk skrzywienia oraz kąta kifozy piersiowej a parametrami oddechowymi u nastoletnich chorych ze SI, kierowanych do leczenia operacyjnego.

\section{Materiał i metody}

Badanie spirometryczne i badanie radiograficzne wykonano u 31 pacjentów z rozpoznaną SI, w wieku 12-18 lat (średnia $14.7 \pm 1.85$ ) przygotowywanych do leczenia operacyjnego. Przeprowadzono analizę korelacji i regresji liniowej, aby ocenić zależność między pomiarami radiologicznymi a parametrami oddechowymi- Natężoną Pojemnością Życiową (FVC) oraz Natężoną Objętością Wydechową Pierwszosekundową (FEVl).

\section{Wyniki}

U 51\% pacjentów wartości parametrów oddechowych były prawidłowe, natomiast u 16\% pacjentów były znacznie obniżone. Stwierdzono istotną statystycznie ujemną korelację między parametrami oddechowymi a wielkością kąta Cobba w odcinku piersiowym kręgosłupa oraz parametrami oddechowymi a liczbą kręgów tworzących łuk skrzywienia. Mogą one wyjaśniać 25.16\% i 26.47\% obserwowanej zmienności FVC i FEVl. Nie stwierdzono istotnej korelacji między parametrami spirometrycznymi a kątem kifozy piersiowej.

\section{Wnioski}

Prawidłowe wartości parametrów oddechowych występowały u połowy chorych z SI zakwalifikowanych do leczenia operacyjnego. Wielkość kąta Cobba oraz liczba kręgów tworzących łuk skrzywienia ujemnie korelują z parametrami oddechowymi u dzieci ze skoliozą idiopatyczną.

Słowa kluczowe: badania spirometryczne, skolioza idiopatyczna, parametry radiologiczne 


\section{Introduction}

Idiopathic scoliosis is a three-dimensional spine and trunk deformity that may negatively influence pulmonary function by reducing the lung volumes especially when the curve is localized in the thoracic region (Weinstein, 1999). Several studies investigated the possible factors that may contribute to severity of pulmonary impairment in adolescents with idiopathic scoliosis. Kotani et al. (2004) suggested that one of the features of the respiratory impairment in patients with idiopathic scoliosis is a limitation of the chest wall mobility. Rib cage deformity may increase stiffness of the chest wall and reduce the force of respiratory muscles and the mechanical dysfunction of the diaphragm.

Wen's et al. (2016) study showed that lung volumes determined on the CT scans are lower in patients with adolescent idiopathic scoliosis than in aged-matched controls. Also, the study revealed that there is a positive correlation between volume of the right lung determined on the CT scans and the values of the pulmonary parameters.

Several researchers confirmed the correlation of pulmonary parameters (considered as percent of predicted value of Forced Vital Capacity and percent of predicted value of Force Expiratory Volume in one second) and radiological measurements- the thoracic curve magnitude in the frontal plane (Jackson, 1989; Kearon, 1993; Upadhyay, 1995; Johnston, 201 1; Newton, 2005) and number of the vertebrae involved in the curve (Kearon, 1993; Newton, 2005). However, conclusions about association between thoracic kyphosis angle and pulmonary function were not consistent. Upadhyay et al. (1995) revealed no correlation between FVC, FEVI and angle of thoracic kyphosis. However, Kearon et al. (1993) concluded that the loss of normal thoracic kyphosis was a significant factor influencing pulmonary function.

Weinstein et al. (1981) suggested that there was a significant correlation between Forced Vital Capacity (FVC), Forced Expiratory Volume in one second (FEVl) and increasing severity of the thoracic curve, but the reduction of the pulmonary function occurred when the Cobb angle was greater than 100o-120o. However, Newton's et al. (2005) findings suggested that the pulmonary function deficit may occur in patients with smaller curves.

Pulmonary function is considered normal when FVC and FEVl predicted value are above $80 \%$. Results below that threshold suggest pulmonary impairment: mild (70\% $\leq$ FVC, FEVI < 80\%), moderate $(60 \% \leq \mathrm{FVC}$, $\mathrm{FEVl}<70 \%)$, severe (50\% > FVC, FEVl $\geq 35 \%$ ) [9]. However, Newton et al. (2005) and Johnston et al. (2011) refer to different stratification of the pulmonary impairment. While the threshold for the normal pulmonary function is unchanged, the value below that indicated: mild ( $80 \% \geq \mathrm{FVC}$, FEVl > 65\%), moderate $(65 \geq \mathrm{FVC}, \mathrm{FEVl}>50 \%$ ) or severe (FVC, $\mathrm{FEVl}<50 \%$ ) pulmonary impairment.

Floresa et al. (2016) suggested that adolescent patients with idiopathic scoliosis presented impairment in muscles strength and significantly decreased values of the FEVl, FVC and PEF comparing to aged-matched control group. They concluded that the preoperative muscle strengthening training may be beneficial for the patients with adolescent idiopathic scoliosis.

Furthermore, Laurentowska et al. (2009) suggested that the comprehensive rehabilitation program may have a positive effect on pulmonary function after surgical treatment in patients with idiopathic scoliosis. Also, they concluded that in patients after thoracoplasty endurance rehabilitation program may improve respiratory muscles capacity.

\section{Aim}

The aim of the study was to analyze the relations of thoracic curve angle, the number of involved vertebrae and thoracic kyphosis angle versus pulmonary parameters (Forced Vital Capacity, Forced Expiratory Volume in one second) in adolescents with idiopathic scoliosis addressed for surgical treatment. 


\section{Material and methods}

The preoperative radiological and pulmonary assessment was performed in 31 adolescents diagnosed with IS. All patients met inclusion criteria as follows: diagnosed idiopathic scoliosis, Lenke 1 or 3 type, no pulmonary disorder, qualification to surgical treatment, spirometric evaluation.

Pulmonary testing prior to surgery was performed in a sitting position using MicroLoop MK8 spirometer (Micro Medical; Chatham, Kent, UK). Forced Vital Capacity (FVC) and Forced Expiratory Flow in One second (FEVl) were chosen as parameters providing an assessment of the volume and flow function characterizing pulmonary function. Each parameter was examined three times and the single maximal effort was analyzed. Percentages of predicted values of parameters (\%FVC, \%FEVl) were established based on age, gender, body height and weight according to the American Thoracic Society.

Radiographic measurements were performed on standard anteroposterior and lateral radiographs of whole spine. Thoracic curve magnitude was measured using Cobb method on anterior-posterior radiographs (Cobb, 1948). The number of involved vertebrae in the thoracic curve was determined- vertebrae between upper and lower end vertebrae were counted on AP radiographs. The angle of thoracic kyphosis was measured on lateral radiographs from the upper endplate of $\mathrm{T} 2$ to lower end plate of $\mathrm{T} 12$.

The mean value, standard deviation were established. Normal data distribution was analyzed with Shapiro-Wilk test. A correlations analysis was conducted between pulmonary parameters - FVC, percent of FVC predicted values and FEVI, percent of FEVI predicted values-and radiological measurements-thoracic Cobb angle, number of involved vertebrae and thoracic kyphosis angle to determine Pearson correlation coefficiency parameters. The coefficient of multiple regression determination (R2) was calculated for radiological measurements that had significant $\mathrm{p}$ values. The t-student test was used to determine if the thoracic curve magnitude influences pulmonary function. The p level of 0.05 was considered significant. The analysis was performed with Statistica Software (TIBCO Software Inc.).

\section{Results}

The study comprised 31 adolescents -23 girls, 8 boys, aged $12-18$ years old (mean $14.7 \pm 1.85$ ). The mean body height was $1.67 \mathrm{~m} \pm 0.09$, range $1.48-1.82 \mathrm{~m}$ (girls mean $1.64 \mathrm{~m} \pm 0.07$, range $1.48-1.80 \mathrm{~m}$; boys mean $1.76 \mathrm{~m} \pm 0.08$, range $1.58-1.82 \mathrm{~m}$ ). Mean body weight was $57.39 \mathrm{~kg} \pm 13.24$, range $14.79-31.71 \mathrm{~kg}$ (girls mean $54.74 \mathrm{~kg} \pm 12.84$, range $36-96 \mathrm{~kg}$; boys mean $65.0 \mathrm{~kg} \pm 12.0$, range $54-91 \mathrm{~kg}$ ).

The mean Body Mass Index (BMI) was $20.5 \mathrm{~kg} / \mathrm{m}^{2} \pm 3.7$, range $14.8-31.7 \mathrm{~kg} / \mathrm{m}^{2}$ (girls mean $20.3 \pm 3.7 \mathrm{~kg} / \mathrm{m}^{2}$, range $14.8-31.7 \mathrm{~kg} / \mathrm{m}^{2}$; boys mean $21.1 \pm 3.8 \mathrm{~kg} / \mathrm{m}^{2}$, range $16.3-28.1$ $\mathrm{kg} / \mathrm{m}^{2}$ ).

FVC-Forced Vital Capacity; \%FVC-percentage of predicted value for FVC; FEV - Forced Expiratory Flow in One second; \%FEVl - percentage of predicted value for FEVI. All values are presented as mean, standard deviation, minimum and maximum in the brackets.

The boys were significantly taller than girls ( $1.76 \mathrm{~m}$ vs. $1.64 \mathrm{~m}, \mathrm{p}=0.0005)$. Also, the boys had significantly larger FVC values (3.76 L vs. $2.91 \mathrm{~L}, \mathrm{p}=0.01$ ). Although, the FEVI, \%FVC and \%FEVl showed no significant differences (Table 1).

Based on American Thoracic Society standard, in $51 \%$ of adolescents pulmonary parameters were normal ( $\mathrm{FVC}, \mathrm{FEVl}>80 \%$ ), in $23 \%$ suggested mild restriction $(80 \%>F V C$, $\mathrm{FEVl} \geq 70 \%$ ), in $16 \%$ moderate restriction ( $70 \%>\mathrm{FVC}, \mathrm{FEVl} \geq 60 \%$ ), in $10 \%$ severe restriction $(50 \%>\mathrm{FVC}, \mathrm{FEVl} \geq 35 \%)$. If considering stratification proposed by Newton et al. (2005) and Johnston (2011) also, in 51\% of patients pulmonary parameters were normal (FVC, $\mathrm{FEVl}>80 \%$ ), in $33 \%$ mild impairment $(80 \% \geq \mathrm{FVC}$, $\mathrm{FEVl}>65 \%$ ) and in $16 \%$ moderate impairment (65\% $\geq$ FVC, $\mathrm{FEVl}>50 \%$ ).

Significant negative correlations between pulmonary parameters - FVC, FEVl - versus radiological measurements- thoracic curve 
Katarzyna Politarczyk et al.: Relationship between radiological parameters and preoperative pulmonary function...

Table 1. Radiological and pulmonary parameters of patients

\begin{tabular}{|c|c|c|c|c|}
\hline Parameter & $\begin{array}{l}\text { All } \\
\mathrm{N}=31\end{array}$ & $\begin{array}{l}\text { Girls } \\
N=23\end{array}$ & $\begin{array}{l}\text { Boys } \\
\mathrm{N}=8\end{array}$ & $\mathrm{p}$ \\
\hline FVC [Litr] & $\begin{array}{l}3.1 \pm 0.8 \\
(1.58-5.01)\end{array}$ & $\begin{array}{l}2.91 \pm 0.77 \\
(1.58-4.35)\end{array}$ & $\begin{array}{l}3.76 \pm 0.7 \\
(2.69-5.01)\end{array}$ & $0.0100 *$ \\
\hline$\%$ FVC & $\begin{array}{l}81.58 \pm 16.27 \\
(51-125)\end{array}$ & $\begin{array}{l}82.13 \pm 17.73 \\
(51-125)\end{array}$ & $\begin{array}{l}80.0 \pm 11.95 \\
(62-102)\end{array}$ & 0.7557 \\
\hline FEVl [Litr] & $\begin{array}{l}2.61 \pm 0.7 \\
(1.28-3.89)\end{array}$ & $\begin{array}{l}2.41 \pm 0.64 \\
(1.28-3.59)\end{array}$ & $\begin{array}{l}2.94 \pm 0.68 \\
(1.84-3.89)\end{array}$ & 0.0593 \\
\hline$\%$ FEVI & $\begin{array}{l}78.90 \pm 17.23 \\
(41-123)\end{array}$ & $\begin{array}{l}80.04 \pm 17.48 \\
(51-123)\end{array}$ & $\begin{array}{l}75.62 \pm 12.20 \\
(41-95)\end{array}$ & 0.5413 \\
\hline Thoracic Cobb angle $\left[^{\circ}\right]$ & $\begin{array}{l}70.6^{\circ} \pm 12.4 \\
\left(53^{\circ}-104^{\circ}\right)\end{array}$ & $\begin{array}{l}70.96^{\circ} \pm 13.20 \\
\left(53^{\circ}-104^{\circ}\right)\end{array}$ & $\begin{array}{l}66.75^{\circ} \pm 12.51 \\
\left(55^{\circ}-89^{\circ}\right)\end{array}$ & 0.4382 \\
\hline Number of vertebrae & $\begin{array}{l}7 \pm 1 \\
(4-9)\end{array}$ & $\begin{array}{l}7.08 \pm 1.13 \\
(4-9)\end{array}$ & $\begin{array}{l}6.87 \pm 0.99 \\
(5-8)\end{array}$ & 0.6404 \\
\hline $\begin{array}{l}\text { Thoracic kyphosis } \\
\left.\text { angle [ }{ }^{\circ}\right]\end{array}$ & $\begin{array}{l}30.9^{\circ} \pm 13.0 \\
\left(11^{\circ}-54^{\circ}\right)\end{array}$ & $\begin{array}{l}31.91^{\circ} \pm 11.65 \\
\left(11^{\circ}-50^{\circ}\right)\end{array}$ & $\begin{array}{l}27.87^{\circ} \pm 15.23 \\
\left(13^{\circ}-54^{\circ}\right)\end{array}$ & 0.4415 \\
\hline
\end{tabular}

Table 2. Correlations between pulmonary parameters and radiographic measurements tested with Pearson correlation coefficiency

\begin{tabular}{|l|l|l|l|l|}
\hline & FVC & \%FVC & FEVl & $\%$ FEVl \\
\hline Thoracic Cobb angle ["] & $-0.45^{*}$ & $-0.40^{*}$ & $-0.45^{*}$ & $-0.36^{*}$ \\
\hline $\begin{array}{l}\text { Number of involved } \\
\text { vertebrae }\end{array}$ & $-0.40^{*}$ & $-0.24^{*}$ & $-0.41^{*}$ & $-0.26^{*}$ \\
\hline $\begin{array}{l}\text { Thoracic kyphosis } \\
\text { angle ["] }\end{array}$ & 0.27 & 0.35 & 0.32 & 0.36 \\
\hline $\begin{array}{l}\text { \%FVC - percent of FVC predicted values; \%FEVl - percent of FEVl predicted values; } \\
\text { "p }<0.05\end{array}$
\end{tabular}

magnitude and the number of vertebrae involved in the thoracic curve were found as presented in Table 2.

No significant correlation was found between FVC versus thoracic kyphosis and FEVI versus thoracic kyphosis. Also, no significant correlation was found between \%FVC versus thoracic kyphosis and \%FEVl versus thoracic kyphosis angle (Table 2).

Regression analysis revealed that the thoracic Cobb angle and number of vertebrae involved in thoracic curve enable to possibly predict the FVC values. Their contribution is quantified by $\mathrm{R} 2=0.2516$. The FVC value may be explained in a variation of $25.16 \%$ by thoracic Cobb angle and number of vertebrae.

Also, $26.47 \%$ of $\mathrm{FEVl}$ value may be explained by thoracic Cobb angle and the number of vertebrae involved in the thoracic curve (R2=0.2647).

Thoracic curve magnitude impacts the pulmonary parameters- the greater Cobb angle the greater declination of FVC $(p=0.003)$ and FEVl ( $p=0.004)$.

\section{Discussion}

Several studies were conducted to address the influence of different factors namely, chest mobility (Kotani, 2004), braces treatment (Kennedy, 1989; Pehrsson, 2001; Ran, 2016) surgery technique (Vedantam, 2000; Lenke, 2004; Kim, 2007) radiological measurements that may influence pulmonary function in adolescents with idiopathic scoliosis (Jackson, 1989; Kearon, 1993; Upadhyay, 1995; Newton, 2005; Johnston, 2011). 
The aim of the present study was to associate radiographic parameters - thoracic curve magnitude, length and thoracic kyphosis angle with pulmonary parameters in adolescents with idiopathic scoliosis. The study confirmed the relationship between thoracic curve magnitude and thoracic curve length versus FVC and FEVI parameters. No correlation was found between the thoracic kyphosis angle versus pulmonary parameters.

Our study showed a negative correlation between pulmonary function measured by FVC, \%FVC and FEVl, \%FEVl versus thoracic curve magnitude. Similar correlation between the degree of Cobb angle and pulmonary parameters was reported in previous studies. Newton et al. (2005) found that thoracic curve magnitude correlated negatively with percent of predicted value of \%FVC and \%FEVl $(p<0.002)$ in the group of 631 patients. Johnston's et al. (2011) study on 41 untreated adults with idiopathic scoliosis revealed a negative correlation between thoracic curve magnitude greater than $40^{\circ}$ and FVC ( $\mathrm{p}$ 0.008). Upadhyay et al. (1995) results concerning the negative correlation between the thoracic Cobb angle versus percent of FVC predicted values were consisted with results of other authors.

Thoracic hypokyphosis was identified as a factor associated with pulmonary function impairment. However, the results of the previous studies are not consistent. According to Kearon et al. (1993) the loss of normal thoracic kyphosis was a significant factor $(p=0.002)$ contributing to pulmonary impairment. Also, Newton et al. (2005) associated thoracic hypokyphosis $(\mathrm{p}<0.002)$ with decreased pulmonary parameters. On the other hand, Jackson et al. (1989) did not make any conclusion about the effect of hypokyphosis. They concluded that thoracic hyperkyphosis $\left(>50^{\circ}\right)$ was related to decreased pulmonary function. In our study, no statistically significant correlation was found between FVC versus thoracic kyphosis angle and FEVl versus thoracic kyphosis angle.
A factor previously identified as the one that may contribute to pulmonary function decrease was the number of vertebrae forming the curve in the thoracic region. The greater the number, the greater pulmonary impairment. That relation was confirmed in our study and the results are consistent with results presented by other authors (Kearon, 1993; Newton, 2005).

Modified pulmonary impairment stratification was used by Newton et al. (2005) and Johnston et al. (2011) who based on the suggestion that $65 \%$ of predicted value of pulmonary parameters is a minimal healthy level of pulmonary function which probably will not lead to respiratory impairment in adulthood. In Newton's et al. (2005) study, $20 \%$ of the patients with thoracic curve magnitude between $50^{\circ}$ to $70^{\circ}$ and $41 \%$ of the patients with thoracic Cobb angle between $71^{\circ}-80^{\circ}$ had pulmonary impairment (<65\%). In Johnston's et al. study (2011), in $19 \%$ of the patient results showed decrease in pulmonary function. Our results are similar $-16 \%$ of patients presented decreased pulmonary parameters.

The results of the Weinstein's et al. study (1981) conducted on 219 patients with untreated adolescent idiopathic scoliosis suggested that pulmonary function was affected in patients with thoracic curve approaching the threshold $100^{\circ}-120^{\circ}$. However, current studies suggest that pulmonary impairment may occur in patients with smaller curves. It is possible that major thoracic curves affect pulmonary function differently than the compensatory curves- distorting the orientation and functions of the diaphragm or mechanics of the thorax (2005).

Pulmonary parameters values were not corrected for the possible body height reduction due to spine deformation. That may lead to overestimation of the pulmonary function.

\section{Conclusions}

In $51 \%$ of the patients the pulmonary parameters were normal (\%FVC, $\% \mathrm{FEVl}>80 \%$ ) while $16 \%$ presented pulmonary impairment 
(\%FVC and \%FEVl<65\%). The magnitude of the thoracic curve and the number of involved vertebrae correlate negatively with the pulmonary parameters in adolescents with pre-surgical idiopathic scoliosis. Also, the results of the study suggested a usefulness of the spirometric examination in planning the perioperative physiotherapeutic rehabilitation.

\section{REFERENCES}

American Thoracic Society, medical section of the American Lung Association. (1982) 'Evaluation of impairment/disability secondary to respiratory disease,' The American Review of Respiratory Disease, 126(5), pp. 945-951. Cobb, J.R.(1948) 'Outline for the study of scoliosis'. Instructional Course Lecture. The American Academy of Orthopaedics Surgeons, 5, pp. 261-275.

Floresa, F., Cavaleiro, J., Lopes, A.A., Ribeiro, F., Oliveira, A. (2016) 'Preoperative pulmonary function and respiratory muscles strength in Portuguese adolescents with idiopathic', Revista portuguesa de pneumologia, 52(1), pp.52-53.

Jackson, R. P., Simmons, E. H., Stripinis, D. (1989) 'Coronal and sagittal plane spinal deformities correlating with back pain and pulmonary function in adult idiopathic scoliosis', Spine, 14(12), pp. 1391-1397.

Johnston, C. E., Richards, B.S., Sucato, D.J., Bridwell, K.H., Lenke, L.G, Erickson, M., Spinal Deformity Study Group. (2011)‘Correlation of preoperative deformity magnitude and pulmonary function tests in adolescent idiopathic scoliosis', Spine, 36(14), pp. 1096-1102. Kearon, C., Viviani, G.R., Kirkley, A., Killian, K.J. (1993) 'Factors determining pulmonary function in adolescent idiopathic thoracic scoliosis', The American Review of Respiratory Disease, 148(2), pp. 288-294.

Kennedy, J. D., Robertson, C.F., Hudson, I., Phelan, P.D. (1989) 'Effect of bracing on respiratory mechanics in mild idiopathic scoliosis', Thorax, 44(7), pp. 548-553.

Kim, Y. J., Lenke, L.G., Bridwell, K.H., Cheh, G., Whorton, J., Sides, B. (2007) 'Prospective pulmonary function comparison following posterior segmental spinal instrumentation and fusion of adolescent idiopathic scoliosis: is there a relationship between major thoracic curve correction and pulmonary function test improvement?', Spine, 32(24), pp. 2685-2693.

Kotani, T., Minami, S., Takahashi, K., Isobe, K., Nakata, Y., Takaso, M., Inoue, M., Maruta, T., Akazawa, T., Ueda, T., Moriya, H. (2004) 'An analysis of chest wall and diaphragm motions in patients with idiopathic scoliosis using dynamic breathing MRI', Spine, 29(3), pp. 298-302.

Laurentowska, M., Głowacki, M., Michalak, E., Deskur-Śmielecka, E., Barinow-Wojewódzki, A., Pospieszna, B. (2009) „Ocena sprawności układu oddechowego po torakoplastyce u dziewcząt ze skoliozq̨", Ortopedia Traumatologia Rehabilitacja, 6(6), pp. 513-519. Lenke, L. G., Newton, P.O., Marks, M.C., Blanke, K.M., Sides, B., Kim, Y.J., Birdwell, K.H. (2004) 'Prospective pulmonary function comparison of open versus endoscopic anterior fusion combined with posterior fusion in adolescent idiopathic scoliosis', Spine, 29(18), pp. 2055-2060.

Newton, P. O., Faro, F.D., Gollogly, S., Betz, R.R., Lenke, L.G., Lowe, T.G. (2005) 'Results of preoperative pulmonary function testing of adolescents with idiopathic scoliosis. A study of six hundred and thirty-one patients', The Journal of Bone and Joint Surgery. American Volume, 87(9), pp. 1937-1946.

Pehrsson, K., Danielsson, A., Nachemson, A. (2001) 'Pulmonary function in adolescent idiopathic scoliosis: a 25 year follow up after surgery or start of brace treatment', Thorax, 56(5), pp. 388-393.

Ran, B., Fan, Y., Yuan, F., Guo, K., Zhu, X. (2016) 'Pulmonary function changes and its influencing factors after preoperative brace treatment in patients with adolescent idiopathic scoliosis', Medicine, 95(43).

Upadhyay, S. S., Mullaji, A.B., Luk, K.D., Leong, J.C. (1995) 'Relation of spinal and thoracic cage deformities and their flexibilities with altered pulmonary functions in 
adolescent idiopathic scoliosis', Spine, 20(22), pp. 2415-2420.

Vedantam, R., Lenke, L.G., Bridwell, K.H., Haas, J., Linville, D.A. (2000) 'A prospective evaluation of pulmonary function in patients with adolescent idiopathic scoliosis relative to the surgical approach used for spinal arthrodesis', Spine, 25(1), pp. 82-90.

Weinstein, S. L. (1999) 'Natural history', Spine, 24(24), pp. 2592-2600.

Weinstein, S. L., Zavala, D. C., Ponseti, I. V. (1981) 'Idiopathic scoliosis: long-term followup and prognosis in untreated patients', The Journal of Bone and Joint Surgery. American Volume, 63(5), pp. 702-712.

Wen, Y., Kai, S., Yong-Gang, Z., Guo-Quan, Z.,Tian-Xiang, D. (2016) 'Relationship Between Lung Volume and Pulmonary Function in Patients with Adolescent Idiopathic Scoliosis: Computed Tomographic-Based Three-Dimensional Volumetric Reconstruction of Lung Parenchyma', Clinical Spine Surgery, 29(8), pp. 396-400. 